\title{
EFFECT OF SEED SIZE AND SOWING DATES ON GROWTH AND YIELD OF GREEN AND DRY BEAN (Phaseolus vulgaris L)
}

\author{
NOSSER, M. A. AND E. Y. BEHNAN
}

Veg. Res. Dep., Hort. Res. Inst., ARC, Giza Egyp

(Manuscript received 9 May 2011)

\begin{abstract}
This study was conducted during the summer season of 2009 and 2010 at Barrage Horticultural Research Station, Kalubia governorate. The study included two experiments on two bean cultivars (Paulista and Nebraska). The first was to investigate the response of Paulista cultivar (green yield) to seed size (large and small) and planting dates (the first week of February, March and April). The second experiment was to investigate the response of Nebraska cultivar (dry yield) to seed size (large and small) and planting dates (first week of February, March and April). Data were recorded on plant height, number of branches/plant, dry weight of leaves/plant, total green yield, pod weight, pod length, pod thickness, pod width, weight of 100 seed, seed germination percentage, total protein and potassium percentage for Paulista cultivar in the first experiment. While, the characters studied for Nebraska cultivar in the second experiment were plant height, number of branches/plant, dry weight of leaves/plant, total dry seed yield, number of seed/pod, weight of 100 seed, seed germination percentage, total protein, nitrogen and potassium percentages.

Regarding results of the first experiment, sowing large seed size from Paulista cultivar gave higher values of plant height, number of branches, dry weight of leaves/plant, total green yield, pod weight, pod characters, weight of 100 seed and seed germination percentage than those obtained from small seed size in both seasons.

Sowing in the first week of March gave the highest value of plant height, number of branches, dry weight of leaves/plant, total green yield, pod weight, pod characters, weight of 100 seed, seed germination percentage and potassium percentage in both seasons.

Using large seeds and sowing in the first week of March gave the highest values for dry weight of leaves/plant, total green yield, pod weight and seed germination percentage.

Concerning the second experiment, sowing with large seeds from Nebraska cultivar gave the high values in most traits, i.e. plant height, number of branches, dry weight of leaves/plant, total dry seed yield, number of seeds/pod, weight of 100 seed, seeds germination percentage, nitrogen percentage and total protein, compared to small size.

Sowing Nebraska cultivar in the first week of March gave the highest values of plant height, number of branches, dry weight of leaves/plant, total dry seed yield, number of seeds/pod, weight of 100 seed, seed germination
\end{abstract}


percentage, total protein and nitrogen and potassium percentage.

For this study it can be concluded that using the large seed size from the cultivars Paulista (green yield) and Nebraska (dry yield) for the growing and planting in the first week from March gave the highest total yield and yield quality.

\section{INTRODUCTION}

Bean (Phaseolus vulgaris L.) is a popular vegetable crop in Egypt. It is a useful legume for its edible green pods and dry seeds, since it has a great nutritive value due to its high protein content. For increasing bean production to meet the increment in human population we must use high yielding cultivars, increasing total yield through improving the cultural practices such as choosing the standard size of seeds for growing and growing suitable cultivars at the optimum sowing date. The improvement of both quantitative and qualitative traits of bean depends on the presence of size seeds, cultivar and sowing date.

The sowing seed size affect yield and yield components of legume. There are many reports on legumes showing the important effect of seed size. Growing large seeds increased vegetative growth, (Cipollini and Stiles, 1991 on bean, Rifaee et. al. 2004 on faba bean), total yield (White et al. 1992 on common bean, Weber et al., 1996 on Vicia faba, Agung and Mcdonald, 1998 , Rifaee et al., 2004 on faba bean), average pod weight (Cipollini and Stiles, 1991 on bean), number of seeds per pod and seed quality (Cipollini and Stiles, 1991 on bean, Loss and Siddique, 1997, Agung and Mcdonald, 1998, Rifaee et al., 2004 on faba bean).

Many reports found that there were significant differences among the tested sowing dates of bean for plant height, number of branches/plant and dry weight of plant (Amer et al., 2002, Abd Alla, 2006, Helal, 2006, Shehata et al., 2007, Ali 2010), total yield (Mohamed, 2001, Amer et al., 2002, Abd Alla, 2006, Helal, 2006, Ullah et al., 2006, Ali 2010), average pod weight and pod character (Mohamed, 2001, Helal, 2006, Shehata et al., 2007), number of seeds/pod and seed quality (Helal and El Sayed, 2000, Muasya et al., 2002, Ali, 2010), seed germination percentage (Helal and El Sayed, 2000, Ali, 2010) and chemical composition of seeds (Helal and El Sayed, 2000, Ali, 2010).

This investigation was carried out to study the effect of seed size and sowing date on plant growth, total yield, pod and seed quality and chemical composition of green pod on two bean cultivars, namely Paulista (green yield) and Nebraska (dry yield). 


\section{MATERIALS AND METHODS}

Two field experiments were carried out during summer 2009 and 2010 seasons at Barrage Horticultural Research Station, Kalubia governorate, to study the response of two bean cultivars, i. e. Paulista (green yield) and Nebraska (dry yield) to sowing with two seed size (large and small) and sowing dates. Air temperatures during the two seasons of this study are presented in Table (1).

Table 1. Maximum and minimum temperatures $\left(C^{\circ}\right)$ in Kalubia governorate during 2009 and 2010 seasons *.

\begin{tabular}{|c|c|c|c|c|}
\hline \multirow{2}{*}{ Month } & \multicolumn{2}{|c|}{ Season 2009 } & \multicolumn{2}{c|}{ Season 2010 } \\
\cline { 2 - 5 } & Max & Min & Max & Min \\
\hline February & 21.07 & 12.00 & 23.39 & 13.32 \\
March & 22.35 & 12.32 & 25.74 & 15.05 \\
April & 27.53 & 16.13 & 28.26 & 16.70 \\
May & 30.07 & 18.32 & 31.39 & 19.67 \\
June & 35.33 & 23.60 & 34.67 & 23.16 \\
\hline
\end{tabular}

*Agricultural Research Center, Central Laboratory for Agricultural Climate Ministry of Agricultural and Land Reclamation.

This study included two field experiments as follows

The first experiment on Paulista cultivar (green yield)

The second experiment on Nebraska (dry yield)

The two experiments were conducted to study the effect of seed size and planting date on vegetative growth, total yield, pod characters and seed quality and chemical composition of the two bean cultivars. Each experiment included six treatments which were the combination of two seed sizes and three planting dates. Three planting dates, i. e. in the first week of February, March and April, in both seasons. Seeds of two bean cultivars were cleaned from residues, broken, defective and foreign material based on weight seed were graded individually in to two seed size categories : Large seeds (weight of 100 seeds was more than 19 and $48 \mathrm{~g}$ for Paulista and Nebraska, respectively) and small seeds (weight of 100 seeds was less than 19 and $48 \mathrm{~g}$ for Paulista and Nebraska, respectively).

The plot area was $7.2 \mathrm{~m}^{2}$ included three rows each one was of $4.0 \mathrm{~m}$ length and $0.6 \mathrm{~m}^{2}$ width. Sowing was done with single seeds spaced at $5 \mathrm{~cm}$ apart. The treatments were arranged in split plot design with four replications where planting dates were arranged in the main plots and seed sizes were arranged in sub plots. The other cultural practices were carried out according to the recommendation of the Ministry of Agriculture.

\section{Data were recorded in the first experiment on Paulista cultivar}

1.1.Vegetative growth characters : A random sample of 10 plants from each sub plot was taken at 50 days from sowing date to determine plant height, number of branches/plant and dry weight of leaves/plant. 


\section{2. Total green yield}

\section{3. Pod characters and seed weight}

Ten pods of each plot were taken at random to determine pod weight, length, thickness, width and weight of 100 seeds.

1. 4. Seed germination percentage : A random sample of 100 seeds from each experimental plot was taken for seed germination test.

1. 5. Chemical composition of green pods: Mineral constituents were determined in the digested dry matter. Total protein was determined by multiplying $\mathrm{N}$ value $\mathrm{x}$ 6.25. the $\mathrm{N}$ value (total nitrogen) was determined using microkieldahl according to Hesse (1971) and, $\mathrm{K}$ was determined using flame photometer according to Jackson (1967).

\section{Data were recorded in the second experiment on Nebraska cultivar}

2. 1. Vegetative growth characters : A random sample of 10 plants from each plot was taken at 50 days after sowing to determine plant height number of branches/plant and dry weight of leaves/plant.

2. 2. Total dry Seed yield.

2. 3. Pod and seed characters (Number of seeds/pod and weight of 100 seeds).

2. 4. Seed germination percentage : A random sample of 100 seeds from each experimental plot was taken for seed germination.

2. 5. Chemical composition of mineral constituents were determined in the digested dry matter. Total nitrogen was determined using microkieldahl according to Hesse (1971) and multiplying $N$ value $\times 6.25$ to calculate total protein, $\mathrm{K}$ was determined using flame photometer according to Jackson (1967).

Data were subjected to statistical analysis according to Snedecor and Cochran (1980).

\section{RESULTS AND DISCUSSION}

\section{First experiment}

\section{1. Vegetative growth characteristics}

\section{1. 1. Effect of seeds size}

Data on growth characters, i. e., plant height, number of branches/plant, and dry weight of leaves/plant, of Paulista cultivar in both seasons are presented in Table (2) using the large seeds for sowing gave higher plant height and number of branches/plant than using the small seeds. The increase in plant growth might be due to that the large seeds produce seedling faster, bigger and have better access to nutrient sources. These results are in agreement with those of Cipollini and Stiles (1991) and Rifaee et. al. (2004), they showed increase in vegetative growth by using the large seed. 
Table 2. Vegetative growth, total green yield ,pod weight and length of Paulista cultivar bean plants as affected by seed size and planting date during 2009 and 2010 seasons.

\begin{tabular}{|c|c|c|c|c|c|c|c|c|c|c|c|c|}
\hline \multirow[t]{2}{*}{ Treatments } & \multicolumn{2}{|c|}{$\begin{array}{c}\text { Plant height } \\
(\mathbf{c m})\end{array}$} & \multicolumn{2}{|c|}{$\begin{array}{c}\text { Number of } \\
\text { branches/ } \\
\text { plant }\end{array}$} & \multicolumn{2}{|c|}{$\begin{array}{c}\text { Dry weight of } \\
\text { leaves/plant (g) }\end{array}$} & \multicolumn{2}{|c|}{ Total yield (ton/fed) } & \multicolumn{2}{|c|}{$\begin{array}{c}\text { Pod weight } \\
\text { (g) }\end{array}$} & \multicolumn{2}{|c|}{$\begin{array}{l}\text { Pod length } \\
\qquad(\mathrm{cm})\end{array}$} \\
\hline & 2009 & 2010 & 2009 & 2010 & 2009 & 2010 & 2009 & 2010 & 2009 & 2010 & 2009 & 2010 \\
\hline & \multicolumn{12}{|c|}{ Seed size } \\
\hline Large seeds & 52.22 & 48.20 & 4.68 & 4.38 & 4.37 & 4.57 & 4.53 & 4.25 & 4.94 & 5.16 & 11.03 & 10.79 \\
\hline Small seeds (S) & 42.69 & 42.60 & 3.60 & 3.47 & 3.82 & 3.97 & 3.68 & 3.38 & 4.03 & 4.58 & 9.79 & 10.31 \\
\hline \multirow[t]{2}{*}{ L. S. D. at 0.05} & 5.67 & 2.32 & 1.02 & 0.39 & 0.07 & 0.16 & 0.41 & 0.29 & 0.82 & 0.38 & 0.68 & NS \\
\hline & \multicolumn{12}{|c|}{ Planting date } \\
\hline $1^{\text {st }}$ week February(F) & 40.55 & 38.13 & 3.17 & 3.26 & 3.58 & 3.81 & 3.09 & 3.10 & 3.70 & 3.78 & 9.42 & 9.39 \\
\hline $1^{\text {st }}$ week March (M) & 56.08 & 51.91 & 4.88 & 4.55 & 4.61 & 4.76 & 4.86 & 4.49 & 5.26 & 5.79 & 11.44 & 11.58 \\
\hline $1^{\text {st }}$ week April (A) & 45.74 & 46.21 & 4.35 & 3.98 & 4.11 & 4.25 & 4.35 & 3.86 & 4.50 & 5.05 & 10.36 & 10.68 \\
\hline \multirow[t]{2}{*}{ L. S. D. at 0.05} & 3.38 & 3.35 & 0.54 & 0.54 & 0.22 & 0.15 & 0.30 & 0.28 & 0.35 & 0.32 & 0.72 & 0.76 \\
\hline & \multicolumn{12}{|c|}{ Seed size $\times$ planting dates } \\
\hline $\mathbf{L} \times \mathbf{F}$ & 44.70 & 42.35 & 3.53 & 3.60 & 3.77 & 4.02 & 3.28 & 3.27 & 3.83 & 3.90 & 9.84 & 9.55 \\
\hline $\mathbf{L} \times \mathbf{M}$ & 62.25 & 55.75 & 5.65 & 5.25 & 5.07 & 5.31 & 5.39 & 5.12 & 5.93 & 6.30 & 12.44 & 11.91 \\
\hline $\mathbf{L} \times \mathbf{A}$ & 49.70 & 46.50 & 4.85 & 4.30 & 4.28 & 4.39 & 4.90 & 4.37 & 5.08 & 5.28 & 10.82 & 10.92 \\
\hline $\mathbf{S} \times \mathbf{F}$ & 36.40 & 33.90 & 2.83 & 2.91 & 3.39 & 3.59 & 2.89 & 2.94 & 3.58 & 3.65 & 9.01 & 9.23 \\
\hline $\mathbf{S} \times \mathbf{M}$ & 49.90 & 48.08 & 4.13 & 3.85 & 4.15 & 4.20 & 4.34 & 3.86 & 4.60 & 5.28 & 10.45 & 11.25 \\
\hline $\mathbf{S} \times \mathbf{A}$ & 41.78 & 45.93 & 3.85 & 3.65 & 3.93 & 4.12 & 3.79 & 3.35 & 3.93 & 4.83 & 9.91 & 10.45 \\
\hline L. S. D. at 0.05 & NS & 4.73 & N S & N S & 0.31 & 0.21 & 0.42 & 0.39 & 0.48 & 0.44 & NS & 1.08 \\
\hline
\end{tabular}




\section{1. 2. Effect of planting date}

Data in Table (2) showed that sowing Paulista cultivar bean in the first week of March gave significant increase in plant height, number of branches/plant and dry weight of leaves/plant followed by the first week of April but first week of February gave the lowest values of these characters in the two growing seasons. The vigour growth of plant under first week of March planting date may be due to the more relatively warm condition during plant growing season (Table 1 air temperature), this could be mainly due to suitable temperatures during the growth period. Similar results were obtained by Amer et al, (2002), Abd Alla (2006), Helal (2006), Shehata et al., (2007) and Ali (2010), they reported that there were significant differences among the tested sowing dates of bean for plant height, number of branches/plant and dry weight of leaves/plant.

\section{1. 3. Effect of interaction between seed size and planting dates}

Data in Table (2) showed that there were not significant differences for seed size and planting dates on plant height in the first season and number of branches/plant in both seasons. While there were significant differences in plant height in the second season and dry weight of leaves/plant in both seasons. Growing large seeds during first March gave the highest plant height in the second season and gave the highest dry weight of leaves/plant in both seasons.

\section{2. Total green yield}

\section{2. 1. Effect of seed size}

Results showed that sowing large seeds gave total green yield higher than the sowing small seeds in both seasons (Table 2). These results could be due to that large seeds gave higher vegetative growth than small seeds (Table 2). These results agree with those reported by white et al. (1992), Weber et al. (1996), Agung and Mcdonald (1998) and Rifaee et al. (2004). They found that growing large seeds increased total yield.

\section{2. 2. Effect of planting dates}

Results in Table (2) indicated that total green yield were significantly affected by planting date in the both seasons. The highest total green yield were obtained by sowing in the first week of March followed by the first week of April planting date. It could be concluded that the optimal sowing date in this study was the first week of March. The results might be due to the temperature degrees in this period were more suitable for growth, flowering, fruit set and in the final increased the yield. These results are confirmed with those reported by Mohamed (2001) , Amer et al. (2002), Abd Alla (2006), Helal (2006), Ullah et al. (2006), and Ali (2010). They found that the total yield of bean was affected significantly by the different growing dates. 


\section{2. 3. Effect of interaction between seed size and planting dates}

Data in Table (2) indicated that there were significant differences in both seasons. Growing large seeds in the first week of March gave the highest value from total green yield in both seasons.

\section{3. Pod characters and weight of $\mathbf{1 0 0}$ seed}

\section{3. 1. Effect of seed size}

Results in Tables (2 and 3) showed that seed size affected significantly pod characteristics in both seasons, except pod length and thickness in the second season. Sowing large seeds gave higher values of average pod weight, pod width and weight of 100 seed than the small seeds in both seasons. Also large seeds gave pod length and pod thickness higher than small seeds in the first season. Similar results are reported by Cipollini and Stiles (1991) who observed that growing large seeds had effect on pod characters.

\section{3. 2. Effect of planting dates}

Data in Tables (2 and 3) indicated that the studied characters were significantly affected by sowing date in both seasons. Average pod weight, length, thickness and width as well as weight of 100 seed were higher by sowing in the first week of March followed by the growing in first week of April. These results are agree with those of Mohamed (2001), Helal (2006) and Shehata et. al., (2007). They showed that planting dates affected pod weight and pod characters.

\section{3. 3. Effect of interaction between seed size and planting dates}

Data in Tables ( 2 and 3 ) showed that the effect of the interaction between seed size and planting dates on pod characters and weight of 100 seed was not significant for pod thickness and significant for pod weight in both seasons. While pod length, weight of 100 seeds and pod width were significantly affected in one season only. In general, sowing with large seed in the first week of March gave highest values of average pod weight, length, pod width and weight of 100 seeds.

\section{4. Seed germination percentage}

\section{4. 1. Effect of seeds size}

Results in Table (3) indicated that germination of seeds obtained from plant sown with large seeds gave germination percentage higher than those obtained from small seeds in both seasons. 
Table 3. Pod characters, 100 seed weight, protein, potassium and germination percentage of Paulista cultivar bean plants as affected by seed size and planting date during 2009 and 2010 seasons.

\begin{tabular}{|c|c|c|c|c|c|c|c|c|c|c|c|c|}
\hline Treatments & \multicolumn{2}{|c|}{$\begin{array}{l}\text { Pod thickness } \\
\text { (mm) }\end{array}$} & \multicolumn{2}{|c|}{$\begin{array}{l}\text { Pod width } \\
\text { (mm) }\end{array}$} & \multicolumn{2}{|c|}{$\begin{array}{c}100 \text { seeds weight } \\
\text { (g) }\end{array}$} & \multicolumn{2}{|c|}{$\begin{array}{c}\text { Total protein } \\
(\%)\end{array}$} & \multicolumn{2}{|c|}{ Potassium $\quad(\%)$} & \multicolumn{2}{|c|}{$\begin{array}{c}\text { Germination } \\
(\%)\end{array}$} \\
\hline & 2009 & 2010 & 2009 & 2010 & 2009 & 2010 & 2009 & 2010 & 2009 & 2010 & 2009 & 2010 \\
\hline & \multicolumn{12}{|c|}{ Seed size } \\
\hline Large seeds & 7.92 & 7.69 & 7.93 & 7.89 & 25.45 & 25.07 & 19.8 & 22.83 & 2.37 & 2.25 & 92.42 & 92.17 \\
\hline Small seeds & 7.43 & 7.58 & 7.42 & 7.39 & 21.01 & 20.59 & 17.90 & 21.83 & 2.03 & 2.14 & 90.50 & 90.67 \\
\hline L. S. D. at 0.05 & 0.492 & NS & 0.24 & 0.46 & 2.35 & 2.69 & 1.6 & NS & 0.27 & NS & 1.17 & 0.52 \\
\hline & & \multicolumn{11}{|c|}{ Planting date } \\
\hline $1^{\text {st }}$ week February (F) & 7.21 & 7.22 & 7.29 & 7.21 & 20.12 & 19.78 & 18.09 & 22.03 & 1.89 & 1.92 & 90.38 & 90.13 \\
\hline $1^{\text {st }}$ week March (M) & 8.25 & 8.15 & 8.09 & 8.20 & 25.91 & 25.41 & 20.52 & 22.98 & 2.93 & 2.68 & 93.13 & 93.25 \\
\hline $1^{\text {st }}$ week April (A) & 7.55 & 7.54 & 7.70 & 7.51 & 23.66 & 23.32 & 17.94 & 21.97 & 1.79 & 1.98 & 90.88 & 90.88 \\
\hline \multirow[t]{2}{*}{ L. S. D. at 0.05} & 0.29 & 0.31 & 0.30 & 0.29 & 1.89 & 1.85 & 0.91 & NS & 0.41 & 0.38 & 0.63 & 0.91 \\
\hline & & & & & \multicolumn{4}{|c|}{ Seed size $\times$ planting dates } & & & & \\
\hline $\mathbf{L} \times \mathbf{F}$ & 7.50 & 7.21 & 7.30 & 7.40 & 22.21 & 20.63 & 18.57 & 22.33 & 1.98 & 1.94 & 90.75 & 90.25 \\
\hline $\mathbf{L} \times \mathbf{M}$ & 8.53 & 8.35 & 8.53 & 8.50 & 29.32 & 28.69 & 22.28 & 23.57 & 3.16 & 2.77 & 94.75 & 95.00 \\
\hline $\mathbf{L} \times \mathbf{A}$ & 7.73 & 7.50 & 8.08 & 7.78 & 24.82 & 25.89 & 18.56 & 22.57 & 1.99 & 2.04 & 91.75 & 91.25 \\
\hline $\mathbf{S} \times \mathbf{F}$ & 6.93 & 7.23 & 7.28 & 7.03 & 18.03 & 18.92 & 17.62 & 21.73 & 1.82 & 1.91 & 90.0 & 90.0 \\
\hline $\mathbf{S} \times \mathbf{M}$ & 7.98 & 7.95 & 7.65 & 7.90 & 22.51 & 22.13 & 18.75 & 22.39 & 2.69 & 2.59 & 91.50 & 91.50 \\
\hline $\mathbf{S} \times \mathbf{A}$ & 7.38 & 7.58 & 7.33 & 7.25 & 22.49 & 20.74 & 17.31 & 21.36 & 1.59 & 1.92 & 90.00 & 90.50 \\
\hline L. S. D. at 0.05 & NS & NS & 0.43 & NS & NS & 2.62 & 1.28 & NS & NS & NS & 0.89 & 1.29 \\
\hline
\end{tabular}




\section{4. 2. Effect of planting percentage}

Data in Table (3) showed that seed germination percentage was significantly affected by planting date in both seasons. Sowing seeds in the first week of March significantly improved germination percentage of the produced seeds in both seasons. The increasing in germination percentage in the first week of March may be due to the suitable temperature during seed formation and development. Obtained results are similar to those reported by Helal and Elsayed (2000) and Ali (2010), they obtained that the seed germination percentage was affected by the sowing.

\section{4. 3. Effect of interaction between seed size and planting dates}

Data in Table (3) revealed that sowing with Large seed in the first week of March planting date gave seeds having the highest values of seed germination percentage in interaction between seed size and planting dates on seeds germination percentage in both seasons.

\section{5. Chemical composition for Paulista}

\section{5. 1. Effect of seed size}

Results in Table (3) indicated that growing large seeds from Paulista cultivar produced seeds having higher total protein and $\mathrm{K}$ percentage. However, the differences were not significant in the second season.

\section{5. 2. Effect of planting dates}

Data in Table (3) showed that there were significant differences among the times of sowing as for the content of protein in the first season and $\mathrm{K}$ percentage in both seasons. The first week of March sowing gave the highest protein content and $K$ percentage. These results confirmed with those of Helal and El Sayed, (2000), Helal (2006) and Ali (2010). They reported that planting date affect of chemical composition in green pod.

\section{5. 3. Effect of interaction between seed size and planting date}

Data on Table (3) observed that there were not significant differences in the interaction between seeds size and planting dates on total protein in the second season and $\mathrm{K} \%$ in both seasons. In the first season, total protein gave highest value in seeds produced from sowing large seed in the first week of March.

\section{Second experiment}

\section{1. Vegetative growth characters}

\subsection{Effect of seed size}

Data on growth characters, i. e. plant height, number of branches/plant and dry weight of leaves/plant on Nebraska cultivars in both seasons are presented in Table (4). Sowing large seeds gave higher plant height, number of branches per plant and dry weight of leaves/plant in both seasons. These results may be due to that the large seeds gave the faster emergence, larger seedling and have better access to nutrient sources. Similar results were obtained by Cipollini and Stiles (1991) and Rifaee et al. (2004). They found improvement in vegetative growth by useing the large seed. 
Table 4. Vegetative growth, total seed yield, number of seed/pod and weight of 100 seeds of Nebraska cultivar bean plants as affected by seed size and planting date during 2009 and 2010 seasons.

\begin{tabular}{|c|c|c|c|c|c|c|c|c|c|c|c|c|}
\hline Treatments & \multicolumn{2}{|c|}{$\begin{array}{c}\text { Plant height } \\
\text { (cm) }\end{array}$} & \multicolumn{2}{|c|}{$\begin{array}{c}\text { Number of } \\
\text { branches / plant }\end{array}$} & \multicolumn{2}{|c|}{$\begin{array}{c}\text { Dry weight of } \\
\text { leaves/plant (g) }\end{array}$} & \multicolumn{2}{|c|}{$\begin{array}{c}\text { Total seed yield } \\
(\mathrm{kg} / \mathrm{fed})\end{array}$} & \multicolumn{2}{|c|}{$\begin{array}{l}\text { Number of } \\
\text { seeds/pod }\end{array}$} & \multicolumn{2}{|c|}{$\begin{array}{c}\text { Weight of } 100 \text { seed } \\
(\mathrm{g})\end{array}$} \\
\hline & 2009 & 2010 & 2009 & 2010 & 2009 & 2010 & 2009 & 2010 & 2009 & 2010 & 2009 & 2010 \\
\hline & \multicolumn{12}{|c|}{ Seed size } \\
\hline Large seeds & 41.92 & 42.28 & 3.42 & 3.72 & 5.50 & 5.64 & 954.86 & 874.83 & 4.66 & 4.45 & 63.25 & 55.95 \\
\hline Small seeds & 34.60 & 38.40 & 2.82 & 3.23 & 4.86 & 4.76 & 630.48 & 648.33 & 3.24 & 3.45 & 53.77 & 47.17 \\
\hline L. S. D. at 0.05 & 2.32 & 1.51 & 0.37 & 0.29 & 0.40 & 0.27 & 110.27 & 138.68 & 0.52 & 0.56 & 5.32 & 3.48 \\
\hline & \multicolumn{12}{|c|}{ Planting date } \\
\hline $1^{\text {st }}$ week February(F) & 35.55 & 35.50 & 2.26 & 3.01 & 4.84 & 4.69 & 634.13 & 599.13 & 3.01 & 2.93 & 50.11 & 48.11 \\
\hline $1^{\text {st }}$ week March $(M)$ & 40.86 & 43.71 & 3.74 & 3.78 & 5.73 & 5.76 & 969.38 & 916.75 & 5.10 & 4.90 & 63.70 & 56.22 \\
\hline $1^{\text {st }}$ week April (A) & 38.35 & 41.78 & 3.35 & 3.63 & 4.96 & 5.13 & 772.38 & 764.38 & 3.74 & 4.03 & 61.74 & 50.32 \\
\hline \multirow[t]{2}{*}{ L. S. D. at 0.05} & 2.93 & 5.19 & 0.53 & 0.20 & 0.30 & 0.23 & 80.37 & 97.13 & 0.39 & 0.47 & 3.35 & 5.17 \\
\hline & \multicolumn{12}{|c|}{ Seed size $\times$ planting dates } \\
\hline $\mathbf{L} \times \mathbf{F}$ & 37.60 & 37.85 & 2.60 & 3.08 & 5.08 & 5.18 & 730.51 & 667.50 & 3.60 & 3.23 & 52.54 & 51.95 \\
\hline $\mathbf{L} \times \mathbf{M}$ & 45.63 & 46.85 & 4.10 & 4.15 & 6.17 & 6.28 & 1198.75 & 1095.75 & 6.10 & 5.65 & 71.03 & 61.64 \\
\hline $\mathbf{L} \times \mathbf{A}$ & 42.53 & 42.13 & 3.55 & 3.93 & 5.24 & 5.47 & 932.75 & 852.25 & 4.28 & 4.48 & 66.18 & 54.26 \\
\hline $\mathbf{S} \times \mathbf{F}$ & 33.50 & 33.15 & 1.93 & 2.95 & 4.60 & 4.20 & 537.75 & 530.75 & 2.43 & 2.63 & 47.69 & 44.28 \\
\hline $\mathbf{S} \times \mathbf{M}$ & 36.10 & 40.58 & 3.38 & 3.40 & 5.29 & 5.24 & 740.02 & 737.80 & 4.10 & 4.15 & 56.36 & 50.80 \\
\hline $\mathbf{S} \times \mathbf{A}$ & 34.18 & 41.43 & 3.15 & 3.33 & 4.67 & 4.84 & 612.13 & 676.50 & 3.20 & 3.58 & 57.30 & 46.38 \\
\hline L. S. D. at 0.05 & NS & NS & NS & 0.28 & NS & N S & 113.65 & NS & 0.56 & NS & 4.74 & NS \\
\hline
\end{tabular}




\section{1. 2. Effect of planting date}

Data presented in Table (4) indicated that Nebraska cultivar bean sown in the first week of March gave significant increase in plant height, number of branches/plant and dry weight of leaves/plant followed by the first week of April without significant difference between them. The obtained increase in vegetative growth might be due to more relatively warm condition during plant growth (Table 1 temperature). This could be mainly due to suitable temperature during the vegetative growth period. Similar results are reported by Amer et al. (2002), Abd Alla (2006), Helal (2006), Shehata et al. (2007) and Ali (2010). They found that planting dates in bean effected on vegetative growth.

\section{2 .1 .3. Effect of interaction between seed size and planting dates}

Data in Table (4) indicated that there were not significant differences for seed size and planting date on plant height and dry weight of leaves/plant in both season, and number of branches/plant in the first season. While there were significant differences in number of branches/plant in the second season. Sowing the large seeds during in the first week of March gave the highest number of branches/plant.

\section{2. Total dry seed yield}

\section{2. 1. Effect of seed size}

Results in Table (4) revealed that growing large seed from Nebraska cultivar gave higher dry seed yield than growing small seeds in both seasons. This result might be due to that growing large seeds gave higher vegetative growth than growing the small seeds and in the final increased the seed yield. These results are in agreement with those of white et. al., (1992), Weber et. al. (1996) Agung and Mcdonald (1998) and Rifaee et. al. (2004). They found that growing large seeds increased total yield.

\section{2. 2. Effect of planting date}

Data in Table (4) showed that the total dry seed yield were significantly affected by sowing dates in both seasons. The highest total dry seed yield in Nebraska cultivar was obtained by sowing in the first week of March followed by the first week of April planting date. The results might be due to the temperature degrees at this dates is more suitable for growth, flowering, fruit set and therefore increased the seed yield. Similar results were obtained by Mohamed (2001), Amer et. al. (2002), Abd Alla (2006), Helal (2006), Ullah et. al. (2006) and Ali (2010) who found that planting dates effected on total dry seed yield of bean. 


\section{2. 3. Effect of interaction between seed size and planting dates}

Data in Table (4) showed observed that significant differences were detected in interaction between seed size and planting dates on total dry seed in Nebraska cultivar in the first season but in the second season the differences were not significant. Large seeds sown in the first week of March planting date gave the highest value of total dry seed yield.

\section{3. Pod and seed characters}

\section{3. 1. Effect of seed size}

Data presented in Tables (4) showed that growing large seed gave higher values for number of seeds/pod and weight of 100 seeds of Nebraska cultivar than growing the small seeds. Similar results are reported by Cipollini and Stiles(1991) and Loss and Siddique (1997). They showed that growing large seeds increased the number of seeds/pod and seed characters.

\section{2 .3. 2. Effect of planting dates}

Data in Tables (4) found that Nebraska cultivar bean sown in the first week of March gave significant increase indicated in number of seeds/pod and weight of 100 seed in both seasons followed by first April without significant differences between them in weight of 100 seed in the first season. These results agree with those of Helal and El Sayed (2000), Muasya et. al. (2002) and Ali (2010). They showed that there were significant differences among the tested cultivars due to sowing dates of bean for number of seeds/pod and seed characters.

\section{3. 3. Effect of interaction between seed size and planting dates}

Data in Tables (4) showed that significant differences were obtained in interaction between seed size and planting dates on number of seed/pod and weight of 100 seed in the first season, but no significant effect was noticed in the second season. Large seed sown in the first week of March planting date gave the highest values of number of seed/pod and weight of 100 seed.

\section{4. Seeds germination percentage}

\section{4. 1. Effect of seeds size}

Data in Table (5) showed that growing large seeds differed significantly seeds germination percentage in both seasons. Growing large seeds gave higher value of seed germination percentage for the produced seeds than those produced from sowing small seeds in both seasons. 
Table 5. Nitrogen, protein and potassium percentage as well as germination of Nebraska cultivar bean plants as affected by seeds size and planting date during 2009 and 2010 seasons.

\begin{tabular}{|c|c|c|c|c|c|c|c|c|}
\hline Treatments & \multicolumn{2}{|c|}{$\begin{array}{c}\text { N percentage } \\
(\%)\end{array}$} & \multicolumn{2}{|c|}{$\begin{array}{c}\text { Total protein } \\
(\%)\end{array}$} & \multicolumn{2}{|c|}{$\begin{array}{c}\text { Potassium } \\
(\%)\end{array}$} & \multicolumn{2}{|c|}{$\begin{array}{c}\text { Germination } \\
(\%)\end{array}$} \\
\hline & 2009 & 2010 & 2009 & 2010 & 2009 & 2010 & 2009 & 2010 \\
\hline & & & & & & & & \\
\hline Large seeds & 3.63 & 3.59 & 22.66 & 22.47 & 2.31 & 2.10 & 92.0 & 92.83 \\
\hline Small seeds & 3.42 & 3.28 & 21.36 & 20.57 & 2.18 & 1.85 & 89.7 & 90.50 \\
\hline L. S. D. at 0.05 & 0.11 & 0.10 & 0.71 & 0.50 & NS & 0.15 & 0.96 & 1.37 \\
\hline & & & & \multicolumn{2}{|c|}{ Planting date } & & & \\
\hline 1 st week February (F) & 3.31 & 3.18 & 20.68 & 19.90 & 1.84 & 1.70 & 89.75 & 90.63 \\
\hline 1 st week March (M) & 3.89 & 3.85 & 24.35 & 24.07 & 2.79 & 2.46 & 92.50 & 93.38 \\
\hline 1 st week April (A) & 3.36 & 3.28 & 20.99 & 20.58 & 2.09 & 1.76 & 90.25 & 90.0 \\
\hline L. S. D. at 0.05 & 020 & 0.27 & 1.25 & 1.66 & 0.55 & 0.30 & 0.99 & 0.88 \\
\hline & & & \multicolumn{4}{|c|}{ Seeds size $\times$ planting dates } & & \\
\hline $\mathbf{L} \times \mathbf{F}$ & 3.46 & 3.34 & 21.63 & 20.85 & 1.91 & 1.98 & 90.25 & 91.0 \\
\hline $\mathbf{L} \times \mathbf{M}$ & 4.01 & 4.04 & 25.09 & 25.27 & 2.91 & 2.63 & 94.25 & 95.50 \\
\hline $\mathbf{L} \times \mathbf{A}$ & 3.40 & 3.41 & 21.25 & 21.28 & 2.13 & 1.71 & 91.50 & 92.0 \\
\hline $\mathbf{S} \times \mathbf{F}$ & 3.16 & 3.03 & 19.73 & 18.95 & 1.77 & 1.43 & 89.75 & 90.25 \\
\hline $\mathbf{S} \times \mathbf{M}$ & 3.78 & 3.66 & 23.61 & 22.88 & 2.69 & 2.29 & 90.75 & 91.25 \\
\hline $\mathbf{S} \times \mathbf{A}$ & 3.32 & 3.18 & 20.73 & 19.87 & 2.06 & 1.82 & 89.0 & 90.0 \\
\hline L. S. D. at 0.05 & NS & NS & NS & N.S & NS & NS & NS & 1.24 \\
\hline
\end{tabular}




\section{4. 2 . Effect of planting dates}

Results in Table (5) indicated that seed germination percentage were significantly affected by planting date in both seasons. The highest seed germination percentage was obtained for seeds obtained from plants grown from sowing in the first week of March. These results agree with those reported by Helal (2006) and Ali (2010) who observed that the seed germination percentage of legume was affected by different growing dates.

\section{2 .4 .3. Effect of interaction between seed size and planting date}

Results in Table (5) showed that significant differences were observed in interaction between seed size and planting dates on seeds germination percentage in second season. In second season growing large seeds in the first week of March planting date produced seeds with the highest value of seed germination percentage.

\section{5. Chemical composition for Nebraska}

\section{5. 1. Effect of seed size}

Sowing large seeds from Nebraska cultivar increased significantly total protein and $\mathrm{N}$ percentage in both seasons and $\mathrm{K}$ percentage in the second season in Table (5).

\section{5. 2. Effect of planting date}

Results in (Table 5) showed that significant differences the times of planting dates for the content of protein among $\mathrm{N}$ percentage and $\mathrm{K}$ percentage in both seasons. The first week of March plantation gave the highest values of protein, $\mathrm{N}$ and K percentages. Similar results are reported by Helal and El Sayed, (2000), Helal (2006) and Ali (2010), who found that the chemical composition was affected by planting dates.

\section{5. 3. Effect of interaction between seed size and planting date}

Data in Table (5) illustrated that there were not significant differences in the interaction between seed size and planting dates in total protein, $\mathrm{N}$ and $\mathrm{K}$ percentages in both seasons.

\section{CONCLUSION}

Regarding to the previous results it could be concluded that the use the large seed for the growing and sowing date in the first week of March was the most favorable treatment for producing Paulista (green bean) and Nebraska (dry yield) cultivars and improved the quality of pods and seeds. 


\section{REFERENCES}

1. Abd Alla, M. S. A. 2006. Physiological studies on the role of some bioregulators in growth, flowering and yield of snap bean. Ph. D. Thesis, Fac. Agric. Benha niv., Egypt, 128 pp.

2. Agung, S. and G. K. Mcdonald. 1998. Effect of seed size and maturity on the growth and yield of faba bean (Vicia faba L.) Australiar J. Agric. Res. 49 : 79-88.

3. Ali, T. G. A. 2010. Physiological studies on growth, seed yield and its quality of common bean. Ph. D. Thesis, Fac. Agric. Benha Univ., Egypt, 115 pp.

4. Amer, A. H. , O. M. Sawan and S. R. Salmam. 2002. Water requirements of snap bean (Phageouls vulgaris L.) as affected by sowing date under newly reclaimed soil at shork El Owinat region. J. Agric. Sci. Mansoura Univ., 27 (9) : 6097-6107.

5. Cipollini, M. L. and E. W. Stites. 1991. Seed predation by the bean weevil Acanthoscelides obtectus on Phaseolus spices, consequences for seed size early growth and reproduction. Oikos $60: 205-214$.

6. Helal, F. A. 2006. Effect of planting date of pole and buch snap bean cultivars on growth, yield and quality for exportation. Egypt J. Appl. Sci. 21 (12A) : 117-134.

7. Helal, F. A. and S. A. El Sayed. 2000. Growth, yield germination seedling vigor and seed quality of some cowpea cultivars as affected by sowing date and foliar nutrition with potassium F. and No vatrein. Zagazig J. Agric. Res. 27 (4) : 875898.

8. Hesse, P. R. 1971. A Text book of soil chemical analysis (Jhan muttay pupils) London, Great Britation

9. Jackson, M. L. 1967. Soil chemical Analysis. Prentice Hall of India Private Limited Newdelhi.

10. Loss, S. P. and K. H. M. Siddique. 1997. Adaptation of faba bean (Vicia fabe L.) to dryland Mediterraneon type environments I. Seed yield and yield components. Field Crops Res., 52 : 17-28.

11. Mohamed, H. M. 2001. The effect of planting date, density and cultivar on productivity and quality of pole beans (Phageouls vulgaris L.) Grown in cold plastic house. Egypt J. Hort. 28 (2) : 197-206.

12. Muasya, R. M., W. J. M. Lommen and P. C. Strik. 2002. Differences in development of common bean (Phageouls vulgaris L.) crops and pod fractions within a crop : I. Seed growth and maturity. Field Crop Rsearch, 75:63-78.

13. Rifaee, M. A. , M. A. Turk and A. R. M. Tawoha. 2004. Effect of seed size and plant population density on yield and yield component of local bean (Vicia fabe L. Major) International J. Agric. and Biology 6 : 294-299. 
14. Shehata, S. A. , A. H. Hassan, S. M. El Gizy and N. S. Turkey. 2007. Improving metabolic and agronomic performance of bean under high temperature stress condition by using and antioxidants, amino acid and shading of maize. Egypt. J. Appl. Sci. 22 (2A) : 332 -350.

15. Snedecor, G. W. and W. G. Cochran. 1980. Statistical Methods. $7^{\text {th }}$ Ed. Iowa State Univ. Press, Ames, Iowa.

16. Ullah, N. J., H. M. T. Hossain and M. A. Baqque. 2006.Yield response of bunch bean (Phageouls vulgaris L.) to dose of fertilizers and sowing times in Banglades Korean J. Crop Sci. $51: 6,496$.

17. Weber, H. , H. L. Borisjuk, and U. Wobus. 1996. Controlling seed development and seed size in (Vicia fabe L.) a role for seed coat associated invertases and carbohydrate Status. The Plant J. , $10: 823-834$.

18. White, J. W., S. P. Singh , C. Pino , M. J. Riosand and I. Buddenhagen. 1992. Effect of seed size and photoperiod response on crop growth and yield of common bean. Field Crops Res. 28 : 295-307. 


\title{
تاثير حجم البذره ومواعيد الزراعه على نمو ومحصول الفاصوليا الخضراء والجافه
}

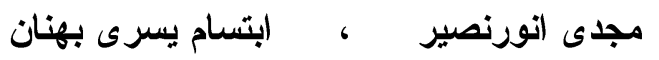 \\ معهز بحوث البساتين - مركز البحوث الزراعية - الجيزه - مصر
}

اجريت هذه الدراسة بمحطة بحوث البساتين بالقناطر الخيرية محافظة القليوبية خلال

الموسمين الصيفيين 2009 و 2010 وتشمل هذه الدراسة تجربتين على صنفين من الفاصوليا هما الصنف بوليستا (محصول اخضر) و الصنف نبر اسكا (محصول جاف)

التجربة الاولى كانت لمعرفة مدى استجابة صنف الفاصوليا بوليستا لحجم البذور المستخدمه فى

الزر اعه (كبيرة - صغيرة) ولمو اعيد الزر اعه (الاسبوع الاول من كل من فبر اير - مارس -

و وابريل).

التجربه الثانيه كانت لمعرفة مدى استجابة صنف الفاصوليا نبر اسكا لحجم البذور المستخدمة فى

الزر اعة (كبيرة - صغيرة) ولمو اعيد الزر اعة (الاسبوع الاول من كل من فبر اير، ومارس ،

و ابريل) • وكانت الصفات المدروسه ارتفاع النبات، عدد الافرع/النبات، الوزن الجاف

للاوراق/النبات، المحصول الكلى الاخضر، وزن القرن، طول القرن، عرض القرن، سمك القرن،

وزن 100 بذره، نسبة انبات البذور، البروتين الكلى ، ونسبة البوتاسيوم فى الصنف بوليستا فى

التجربه الاولى بينما كانت الصفات المدروسه على الصنف نبر اسكا فى التجربة الثانيه هى ارتفاع النبات، عدد الافرع/النبات، الوزن الجاف للاوراق/النبات، المحصول البذرى الكلى، عدد البذور/القرن، وزن 100 بذره، نسبة انبات البذور، البروتين الكلى ، ونسبة النتروجين و البوتاسيوم.

اوضحت نتائج التجربة الاولى ان زر اعة البذور ذات الحجم الكبير من الصنف بوليستا

اعطت اعلى قيم معنوية لصفات ارتفاع النبات، وعدد الافرع/النبات، الوزن الجاف للاور اق/النبات و المحصول الكلى الاخضر ، ومواصفات القرون، وزن 100 بذرهو نسبة انبات البذور بالمقارنه بزر اعة البذور الصغيرة الحجم فى كلا الموسمين. بالنسبة لمو اعيد الزر اعة اعطت زر اعة الصنف بوليستا فى اول شهر مارس اعلى القيم للصفات المدروسه وهى ارتفاع النبات، عدد الافرع، الوزن الجاف للاور اق/النبات، المحصول الكلى الاخضر ، مو اصفات القرن، وزن 100 بذره، نسبة انبات البذور ونسبة البوتاسيوم فى كلا الموسمين. التفاعل بين المعاملات زر اعة البذور كبيرة الحجم من الصنف بوليستا فى الاسبوع الاول

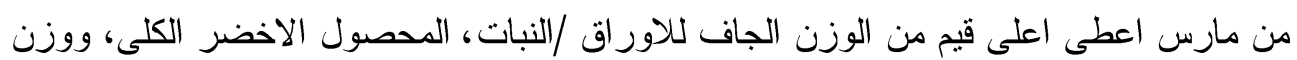

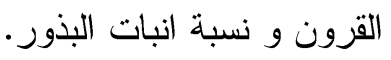


اظهرت نتائج التجربة الثانية ان زر اعة البذور كبيرة الحجم من الصنف نبر اسكا اعطت اعلى قيم معنوية فى معظم الصفات وهى ارتقاع النبات، عدد الافرع، الوزن الجاف للاوراق/النبات، المحصول البذرى الكلى، عدد البذور فى القرن، وزن 100 بذره ، نسبة انبات البذور، نسبة البة النتروجين و البروتين الكلى بالمقارنه بزر اعة البذور صغيرة الحجم. اوضحت النتائج ان زر اعة الصنف نبر اسكا فى الاسبوع الاول من شهر مارس اعطى اعلى قيم من

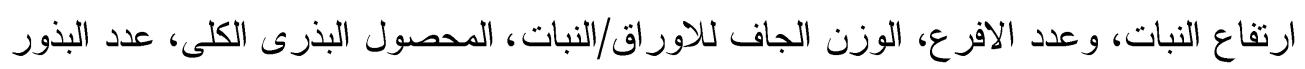

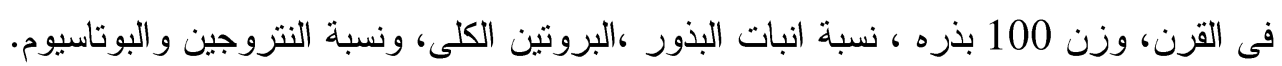
و على ذلك يوصى باستخدام البذور كبيرة الحجم من الاصناف بوليستا (محصول اخضر) ونبر اسكا (محصول جاف) فى الزر اعة فى ميعاد الاسبوع الاول من مارس للحصول على اعلى محصول واحسن جودة للمحصول. 